\title{
Meningkatkan Hasil Belajar Pendidikan Jasmani Olah Raga dan Kesehatan (PJOK) Materi Permainan Bola Kecil Sederhana Melalui Penerapan Model Pembelajaran Langsung
}

\author{
Ni Nyoman Sukarini ${ }^{1^{*}}$ iD \\ ${ }^{I}$ SMP Negeri 4 Abiansemal, Badung, Indonesia \\ *Corresponding author: ninymnsukarini97@gmail.com
}

\section{Abstract}

Penelitian ini bertujuan untuk meningkatkan hasil belajar siswa dengan menggunakan model lansung. Subjek penelitian ini adalah siswa yang berjumlah 30 orang. Penelitian ini merupakan penelitian tindakan kelas yang dilaksanakan dalam dua siklus. Setiap siklus terdiri dari 2 kali pertemuan yang di dalamnya terdiri atas perencanaan, pelaksanaan tindakan, observasi, dan refleksi. Data hasil belajar siswa dikumpulkan melalui lembar observasi aktivitas belajar siswa dan penilaian aspek pengetahuan siswa menggunakan tes. Data yang telah dikumpulkan tersebut dianalisis dengan menggunakan analisis deskriptif. Hasil penelitian ini menunjukkan bahwa penerapan Model Pembelajaran Langsung dalam pembelajaran PJOK dapat meningkatkan hasil belajar siswa. Adapun hasil yang dicapai dalam Penelitian Tindakan Kelas ini adalah: 1) pada aspek sikap pada siklus 1 semua anak sudah mencapai kategori baik sedangkan pada siklus 2, kategori amat baik diraih oleh 3 siswa dan kategori baik dicapai oleh 27 siswa. Jadi aspek sikap sudah mencapai tuntas pada siklus 1. 2) aspek pengetahuan, pada siklus 1 mencapai ketuntasan 70\% dengan nilai rata-rata 75,6, sedangkan pada siklus 2 baru mencapai ketuntasan 100\% dengan nilai rata-rata 81,17. Dan 3) aspek keterampilan, pada siklus 1 mencapai ketuntasan 73,33\% dengan nilai rata-rata 77,01. Sedangkan pada siklus 2 telah mencapai ketuntasan 100\% dengan nilai rata-rata 81,68.

Keywords: Model Pembelajaran Langsung, Hasil Belajar, Permainan Bola Kecil Sederhana

\section{Abstract}

This study aims to improve the student learning outcomes by using a direct model. The subjects of this study were 30 students. This research is a classroom action research which conducted in two cycles. Each cycle consists of 2 meetings which includes planning, implementing actions, observing, and reflecting. Student learning outcomes data were collected through student learning activities observation sheets while assessment of student knowledge aspect is through tests. The data that has been collected were analyzed using descriptive analysis. The results of this study indicate that the application of the Direct Learning Model in learning PJOK can improve student learning outcomes. The results of this Classroom Action Research were: 1) the aspect of attitude in cycle 1 shows that all children had reached the good category while in cycle 2, the very good category was achieved by 3 students and the good category was achieved by 27 students. So the attitude aspect has reached completion in cycle 1.2) the knowledge aspect in cycle 1 reaches $70 \%$ completeness with an average value of 75.6, while in cycle 2 reaches $100 \%$ completeness with an average value of 81.17. And 3) aspects of skills in cycle 1 reaches $73.33 \%$ completeness with an average value of 77.01 . Whereas in cycle 2, it has reached $100 \%$ completeness with an average value of 81.68 .

Keywords: Direct Learning Model, Learning Outcomes, Simple Small Ball Game

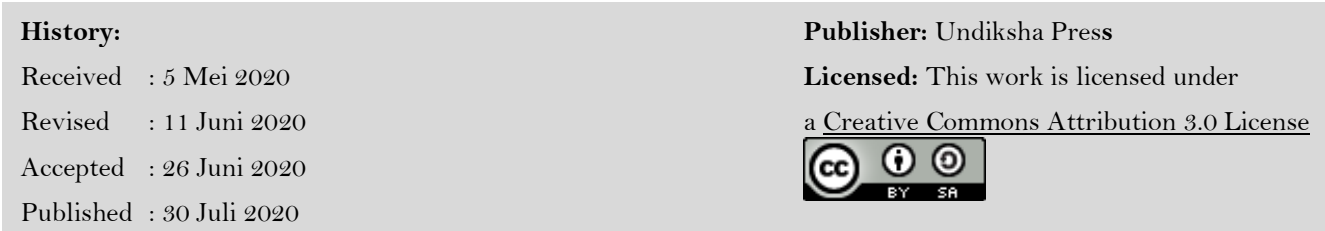




\section{Introduction}

Permainan bola Kecil merupakan salah satu nomor cabang olah raga yang dilaksanakan dalam pembelajaran Pendidikan Jasmani Olah raga dan Kesehatan (PJOK) di SMP kelas VII pada semester Genap. Dalam pembelajaran permainan bola kecil (Bulu Tangkis) dengan materi Teknik dasar memegang Raket ditekankan pada penanaman teknik yang tepat kepada siswa agar siswa dapat melakukannya dengan baik dan benar. Meskipun teknik dasar memegang raket dalam permainan bulu tangkis ini Nampak mudah dalam melakukannya namun masih banyak kesulitan yang dihadapi siswa SMP dalam belajar melakukannya karena teknik dasar memegang raket ini jika dilakukan kurang tepat maka akan menyebabkan kesalahan fatal bahkan bisa mengakibatkan cedera pada tangan bagi siswa dalam melakukan permainan bulu tangkis. Dalam teknik dasar memegang raket dalam permainan bola kecil (bulu tangkis) terdapat empat komponen utama yang perlu dikuasai oleh siswa yaitu: Forehand Grip, Backhand Grip, American Grip, Combination Grip. Kemudian yang tidak kalah pentingnya adalah sikap pada saat melakukan permainan harus juga diperhatikan agar dapat bermain dengan baik dan benar, karena jika sikap dalam bermain bulu tangkis dapat dilakukan oleh siswa dengan baik dan disertai oleh penguasaan teknik dasar memegang raket dengan benar, maka akan mampu bermain dengan maksimal.

Berdasarkan hasil observasi yang peneliti lakukan pada siswa kelas VII.A SMP Negeri 4 Abiansemal terhadap pembelajaran pendidikan jasmani, olah raga dan kesehatan (PJOK) khususnya materi teknik dasar memegang raket. Masalah umum yang diamati adalah hasil belajar siswa belum mencapai nilai standar KKM yang ditentukan oleh sekolah yaitu 64 untuk mata pelajaran PJOK. Siswa belum memahami teknik dasar memegang raket sehingga dalam pembelajaran praktik bulu tangkis siswa belum dapat bermain dengan baik dan benar. Hasil tes persiklus yang dilakukan Peneliti pada tahap awal dari Penelitian Tindakan Kelas ini hasil yang dicapai siswa dengan nilai rata-rata 63,1 dan ketuntasan belajar mencapai 30 $\%$. Rendahnya hasil belajar tersebut berpengaruh pula pada rendahnya mutu pembelajaran PJOK di SMP Negeri 4 Abiansemal.

Pada penelitian memilih solusi Model Pembelajaran Langsung sebagai solusi untuk meningkatkan hasil belajar/kompetensi peserta didik. Model pembelajaran langsung berbeda dengan metode ceramah, model ini menerapkan beberapa metode seperti demonstrasi, tanya jawab, presentasi dan lain-lain. L \& Arsyad, (2015);Rainis, (2019) menyatakan pembelajaran langsung tidak sama dengan metode ceramah, tetapi ceramah dan resitasi (mengecek pemahaman dengan tanya jawab) berhubungan erat dengan model pembelajaran langsung. Eggen dalam Yanti, (2019) menyatakan bahwa Pengajaran Langsung (Direct Instruction) adalah satu model yang menggunakan peragaan dan penjelasan guru digabungkan dengan latihan dan umpan balik siswa untuk membantu mereka mendapatkan pengetahuan dan keterampilan nyata yang dibutuhkan untuk pembelajaran lebih jauh. Model pembelajaran langsung merupakan model pembelajaran yang dapat membantu siswa untuk memahami konsep dasar materi kearsipan dan membantu siswa dalam mempraktekkannya (Neni Mersita, 2015). Sedangkan pendapat Arianti et al., (2017) menyatakan bahwa Melalui model direct instruction, peserta didik dapat memahami konsep tanpa terjadi miskonsepsi, karena guru akan mengarahkan secara langsung materi ajar yang akan dicapai oleh peserta didik. Jadi dapat dikatakan bahwa dengan adanya model pembelajaran langsung siswa akan pembelajaran bersama guru dengan beberapa metode yang ada seperti demonstrasi, tanya jawab dan lain sebagainya. Ahmad, (2016) Model pembelajaran langsung ini menekankan pada wujud aktivitas siswa dalam mengekspresikan pikiran, perasaan dan imajinasinya dengan menggunakan bahasa tulis.

Model pembelajaran langsung ini memilki sintaks/langkah pembelajaran sebagai berikut: 1) menyampaikan tujuan pembelajaran, (2) guru/model mendemonstrasikan pengetahuan, (3) guru membimbing pelatihan, (4) mengecek pemahaman peserta didik dan 
memberikan umpan balik, (5) memberikan kesempatan peserta didik untuk pelatihan selanjutnya dan penerapannya (Ni'mah, 2006). Melalui penerapan model pembelajaran langsung, guru memiliki kesempatan untuk mendemonstrasikan keterampilannya. Begitu pula peserta didik akan memiliki pegangan untuk melatih diri menirukan mengingat dan menirukan keterampilan yang sudah didemonstrasikan oleh guru sebelumnya. Selanjutnya guru memiliki kesempatan untuk mengecek dan memperbaiki kesalahan dan kekurangan peserta didik.

Beberapa penelitian yang sudah dilakukan antara lain oleh Eka Fitriana Hamsyah, St. Hayatun Nur Abu (2017) menyatakan bahwa ada pengaruh positif penggunaan model pengajaran langsung dengan pendekatan meta kognitif terhadap hasil belajar siswa kelas $\mathrm{X}$ SMA Negeri 1 Sungguminasa pada materi pokok ikatan kimia. Multasyam et al. (2016) menyatakan bahwa Hasil penelitian menunjukkan pre-test siswa memperoleh skor rata-rata 7,92 sedangkan post-test diperoleh skor rata-rata 12,74 dan skor rata-rata uji gain ter normalisasi sebesar 0,40. Sehingga dapat disimpulkan bahwa hasil belajar siswa kelas $X$ SMA Handayani Sungguminasa meningkat dalam kategori sedang setelah diterapkan model pembelajaran langsung. Suprapto (2017) menemukan data penelitian dianalisis secara deskriptif dan ANOVA (Analysis of Variance) yang didasarkan pada taraf signifikansi 5\%. Dari hasil penelitian disimpulkan bahwa (1) penggunaan model pembelajaran contextual lebih unggul dibandingkan dengan model pembelajaran langsung terhadap hasil belajar kognitif, (2) ada perbedaan hasil belajar kognitif yang signifikan antara siswa dengan motivasi berprestasi tinggi dan siswa dengan motivasi berprestasi rendah, dan (3) tidak ada interaksi yang signifikan antara model pembelajaran dan motivasi berprestasi pada hasil belajar kognitif. Selain itu Puryadi et al. (2018) menyatakan bahwa terdapat pengaruh yang signifikan penerapan model pembelajaran langsung terhadap hasil belajar siswa.

Berdasarkan uraian di atas, maka perlu dilakukan suatu langkah tepat untuk meningkatkan hasil belajar siswa pada mata pelajaran PJOK terutama pada materi permainan bola kecil (bulu Tangkis). Salah satu upaya yang dilakukan oleh Peneliti adalah melakukan Penelitian Tindakan Kelas yang bertujuan untuk meningkatkan hasil belajar siswa dalam pelajaran PJOK melalui model pembelajaran langsung. Penerapan model pembelajaran langsung memberi kesempatan guru untuk menggunakan metode pembelajaran yang bervariasi, seperti: metode ceramah, metode demonstrasi, metode penugasan, metode Tanya jawab, metode presentasi. Sehingga penerapan model pembelajaran langsung akan membuat situasi pembelajaran menyenangkan dan bermakna. Hal ini sesuai dengan amanat PP No 19 tahun 2005 yang diperbarui dengan PP No 13 tahun 2015.

\section{Materials and Methods}

Penelitian ini dilakukan di Kelas VII.A SMP Negeri 4 Abiansemal, yang beralamatkan di Br. Pengembungan, Bongkasa, Kec. Abiansemal, Kabupaten Badung, Bali 80352 pada Semester genap, dengan rombel belajar 30 tahun pelajaran 2018/2019. Kelas ini adalah kelas yang nilai Pendidikan Jasmani Olah Raga dan Kesehatannya belum mencapai diatas rata-rata kelas, atau masih rendah. Disamping itu peneliti juga guru Penjaskes di SMP Negeri 4 Abiansemal, sehingga pelaksanaan Penelitian dilaksanakan pada kelas yang diajarkan. Subjek penelitian sebanyak 30 orang siswa, dengan jumlah siswa perempuan adalah 19 dan jumlah siswa laki-laki adalah 11. Kelas itu dijadikan sebagai subjek penelitian karena rata-rata hasil tes awal (pra siklus) dengan nilai rata-rata 63,1 dan ketuntasan belajar mencapai 30\%, sehingga perlu segera ditangani.

Waktu penelitian mulai dari perencanaan sampai dengan penulisan laporan hasil penelitian tersebut mulai dari bulan Januari s.d Maret 2019. Pada bulan Februari sampai dengan bulan Juni aktivitas belajar yang sangat tepat bagi Peneliti karena materi permainan bola kecil sesuai dengan program tahunan peneliti muncul pada semester genap, sehingga 
dapat memanfaatkan waktu secara efektif. Rancangan penelitian tindakan kelas di pusatkan pada situasi dalam proses pembelajaran di kelas berlangsung secara kolaborasi. Dalam pelaksanaan proses pembelajaran, mengacu pada rancangan dan program, bahwa rancangan penelitian ini dilakukan atas dasar empiris yang didukung program penelitian tindakan kelas. Untuk mendapat gambaran yang lebih jelas tentang rancangan penelitian tersebut dapat dilihat pada Gambar 1.

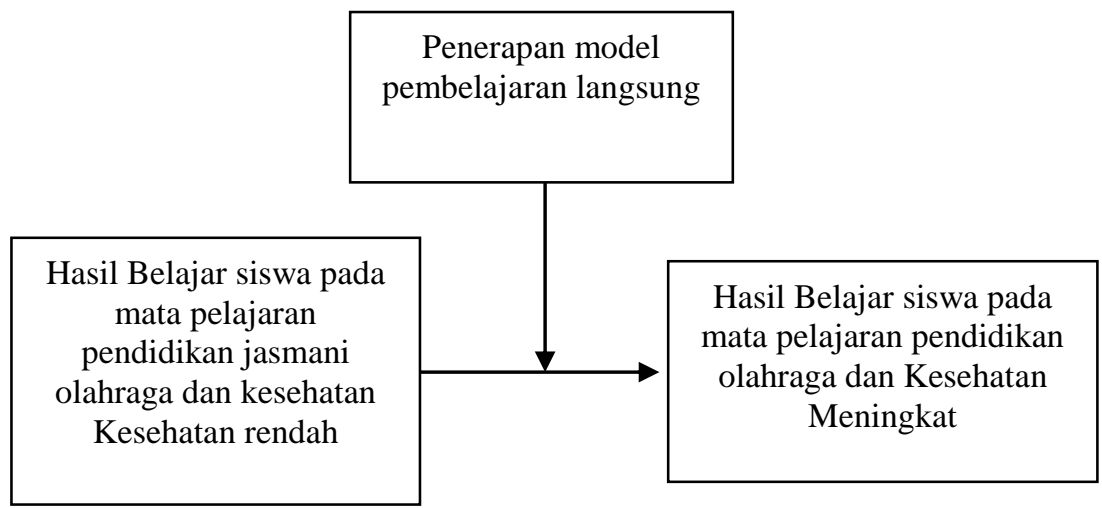

Gambar 1. Rancangan Penelitian

Pelaksananaan Penelitian Tindakan Kelas ini terdiri dari dua siklus, dimana setiap siklus terdiri dari empat komponen yaitu: pertama, pada tahap ini Peneliti menyusun rencana pelaksanaan pembelajaran (RPP), materi pokok pada mata pelajaran Pendidikan Jasmani Olah Raga dan Kesehatan yang akan diajarkan kepada siswa bersama dengan Indikatornya. Pelaksanaan Pada siklus I, II, di rencanakan dalam persiapan ini. Selanjutnya dilakukan pemilihan masalah yang potensial diangkat dalam penelitian ini atau sesuai judul yang telah disetujui dalam proposal Penelitian Tindakan Kelas ini. Pelaksanaan studi pendahuluan, melakukan perumusan masalah, memilih pendekatan yang akan diterapkan dalam penelitian ini, kemudian menentukan variabel dan menentukan sumber data. Mempersiapkan alat dan bahan adalah hal penting dalam penelitian ini, dan penyusunan instrumen tes uji kompetensi serta lembar observasi. Terkait dengan peningkatan kemampuan siswa dalam menganalisis laporan dan menanggapi isi laporan pada pelajaran Pendidikan Jasmani Olah Raga dan Kesehatan melalui penerapan model pembelajaran langsung, maka persiapan kepada siswa diharapkan agar dapat berkosentrasi serta memusatkan perhatiannya untuk mengikuti kegiatan belajar dengan baik. Kedua, kegiatan yang dilakukan pada tahap ini adalah melaksanakan pembelajaran sebagaimana scenario pembelajaran yang telah ditetapkan pada RPP. Ketiga, pada tahap ini dilakukan proses observasi terhadap pelaksanaan tindakan dengan menggunakan lembar observasi yang telah disiapkan, sesuai dengan sasaran aspek penilaian yang mencakup 3 ranah, yaitu: sikap, pengetahuan dan keterampilan yang didemonstrasikan oleh peserta didik. Keempat, Setiap siklus saling berkaitan dan berhubungan, karena hasil refleksi akan digunakan sebagai acuan untuk perbaikan pada siklus berikutnya. Diharapkan setiap siklus ada peningkatan yang signifikan mengenai pembelajaran Pendidikan Jasmani Olah Raga dan Kesehatan dengan kemampuan meningkatkan hasil belajar PJOK, untuk meningkatkan mutu pembelajaran sehingga hasil belajar yang dicapi siswa sesuai tujuan pembelajaran. Peneliti mengadakan perubahan dan peningkatan dalam pelaksanaan pembelajaran di setiap siklus. Dengan melihat perubahan 
sikap siswa sehingga peningkatan hasil belajar mata pelajaran PJOK siswa dapat terobservasi perkembangannya di setiap siklus.

Data hasil belajar siswa dikumpulkan melalui: 1) tes praktik, 2) lembar observasi, dan 3) wawancara. Setelah data terkumpul, selanjutnya dilanjutkan pada tahap analisis data menggunakan analisis statistik deskriptif. Indikator keberhasilan penelitian ini adalah meningkatnya hasil belajar siswa kelas VII.A SMP Negeri 4 Abiansemal terhadap pembelajaran Pendidikan Jasmani Olah Raga dan Kesehatan dan meningkatkan pemahaman siswa terhadap permainan bola kecil sederhana. Penelitian ini bisa dihentikan bila setiap siswa mencapai nilai minimal untuk sikap: baik, pengetahuan dan keterampilan minimal 75.

\section{Results and Discussion}

Penilaian pada perisiklus belum menunjukkan kemampuan yang baik bagi siswa dalam bermain bulu tangkis terutama dalam memegang raket. Siswa belum memahami bagaimana melaksanakan permainan dengan benar. Berdasarkan hasil tes pra siklus dapat di uraikan beberapa hal sebagai berikut.1) Sebanyak 9 orang siswa yang mendapat nilai rata-rata diatas KKM dengan kategori tuntas dalam mencapai hasil belajar mata pelajaran Pendidikan Jasmani Olah Raga dan Kesehatan dengan materi teknik dasar memegang raket dalam permainan bulu tangkis. 2) Sebanyak 21 orang siswa yang mendapat nilai rata-rata dibawah KKM dengan kategori belum tuntas. Nilai Rata-rata yang dicapai pada pra siklus 63,1. Ketercapaian ketuntasan belajar siswa mencapai 30\%. Siswa yang belum tuntas adalah: $70 \%$.

Melihat kondisi yang demikian ini maka Peneliti berupaya memperbaiki hasil belajar siswa dengan memberikan tindakan refleksi di setiap siklus jika hasil belajar siswa belum mencapai target pembelajaran. Dalam melakukan refleksi terhadap siswa yang memperoleh nilai dengan hasil dibawah KKM, Peneliti menerapkan langkah-langkah sesuai yang di tuangkan dalam RPP terlampir. Pada siklus I Peneliti memberikan bimbingan khusus tentang teknik dasar memegang raket dalam bentuk Praktik), sedangkan pembelajaran teori siswa dikembalikan dalam bentuk klasikal.

Pembelajaran yang dilaksanakan pada siklus I telah mencapai peningkatan hasil belajar siswa dalam pelajaran Pendidikan Jasmani Olah Raga dan Kesehatan pada materi Permainan Bola Kecil Sederhana. Hasil belajar yang dicapai siswa menunjukkan peningkatan yang lebih baik dari hasil penilaian pra siklus. Peningkatan hasil pembelajaran ini dicapai karena Peneliti menerapkan Model Pembelajaran Langsung (direct instructin) dimana siswa setelah mengamati model kemudian siswa diberi kesempatan menirukan model secara berpasangan. Saat siswa melakukan peniruan, guru mengamati siswa dengan saksama. Kemudian guru memberi bimbingan secara kontinyu bersama siswa yang sudah bisa melakukan dengan benar sampai mencapai kemahiran dalam melakukan gerakan memegang raket dalam permainan bulu tangkis, dan memukul bola secara berpasangan. Setelah teknik dasar memegang raket, dan memukul bola dikuasai oleh siswa dilanjutkan dengan permainan bulu tangkis sesungguhnya.

Saat permainan tentu tidak semua siswa bisa dilibatkan. Oleh karena itu untuk siswa yang sudah biasa bermain bulu tangkis guru menugaskan mereka untuk ikut menilai kemampuan temanya. Dengan demikian guru akan sangat terbantu dan penilaian bisa dilaksanakan lebih efektif. Pada siklus I, ternyata pada aspek sikap semua siswa sudah berhasil mencapai indikator penelitian. Hal ini tidaklah aneh, karena siswa kelas VII.A ini tinggal di desa bersama orang tua mereka. Keseharian anak-anak ini masih bisa diawasi dan membantu orang tua mereka. Sangat berbeda sekali dengan anak-anak yang keseharian nya tinggal berpisah dengan orang tua mereka. Sehingga anak-anak ini masih sangat mudah diatur.

Pada aspek pengetahuan pada siklus I ini ada anak yang mendapat nilai relatif rendah yaitu seorang anak memperoleh nilai 55 dari indikator ketuntasan 64. Setelah peneliti 
wawancara ternyata anak ini tidak memiliki hp android, sehingga tidak bisa membaca dengan teliti materi ajar yang peneliti kirim melalui WA grup Kelas VII.A. Begitupun sebanyak 9 orang siswa yang mendapat nilai 60 mereka juga tidak memiliki hp android, tetapi mereka sempat membaca materi yang peneliti kirim melalui hp android temanya. Terdapat anak-anak yang tidak memiliki hp android karena masih ada sebagian orang tua yang melarang anaknya memakai HP android, karena para orang tua mendengar efek negatif penggunaan HP android. Sedangkan pada aspek keterampilan, walau masih ada 9 orang anak yang belum tuntas, tetapi nilai yang mereka peroleh masih sedikit dibawah indikator penelitian. Dengan demikian untuk mencapai indikator penelitian tidaklah begitu sulit bagi guru untuk meningkatkan.

Pencapai hasil pada siklus II berdasarkan penerapan Model Pembelajaran Langsung ini, lebih diaktifkan. Bimbingan yang efektif mampu menstimulus siswa secara signifikan, sehingga mampu meningkatkan hasil belajar siswa dalam pelajaran Pendidikan Jasmani Olah Raga dan Kesehatan lebih meningkat dari siklus I. Adapun jumlah nilai rata-rata pada siklus II ini untuk aspek pengetahuan adalah 81,17 dan ketuntasan belajar mencapai $100 \%$. Begitu pula untuk aspek keterampilan nilai rata-ratanya adalah 81,68 dengan ketuntasan $100 \%$. Peningkatan hasil yang dicapai siswa pada siklus II karena dilakukan refleksi, pembinaan dan penguatan secara maksimal melalui dalam pembelajaran. Siswa merasa terbina kemampuannya untuk mahir dalam melakukan gerakan teknik dasar memegang raket dalam permainan bulu tangkis.

Dari data nilai hasil evaluasi siswa kelas VII.A SMP Negeri 4 Abiansemal, pada siklus II yang telah menunjukkan peningkatan, dan adanya peningkatan hasil belajar terhadap penerapan model pembelajaran langsung, pada pembelajaran mata pelajaran Pendidikan Jasmani Olah Raga dan Kesehatan. Dengan demikian penerapan Model Pembelajaran Langsung telah terbukti keberhasilannya dengan baik.

Model Pembelajaran Langsung sebagai solusi untuk meningkatkan hasil belajar/kompetensi peserta didik. Model pembelajaran langsung berbeda dengan metode ceramah, model ini menerapkan beberapa metode seperti demonstrasi, tanya jawab, presentasi dan lain-lain. L \& Arsyad, (2015); Rainis, (2019) menyatakan pembelajaran langsung tidak sama dengan metode ceramah, tetapi ceramah dan resitasi (mengecek pemahaman dengan tanya jawab) berhubungan erat dengan model pembelajaran langsung. Eggen (dalam Yanti, 2019) menyatakan bahwa Pengajaran Langsung (Direct Instruction) adalah satu model yang menggunakan peragaan dan penjelasan guru digabungkan dengan latihan dan umpan balik siswa untuk membantu mereka mendapatkan pengetahuan dan keterampilan nyata yang dibutuhkan untuk pembelajaran lebih jauh. Model pembelajaran langsung merupakan model pembelajaran yang dapat membantu siswa untuk memahami konsep dasar materi kearsipan dan membantu siswa dalam mempraktekkannya (Neni Mersita, 2015). Sedangkan Arianti et al. (2017) menyatakan bahwa Melalui model direct instruction, peserta didik dapat memahami konsep tanpa terjadi miskonsepsi, karena guru akan mengarahkan secara langsung materi ajar yang akan dicapai oleh peserta didik. Jadi dapat dikatan bahwa dengan adanya model pembelajaran langsung siswa akan belajaran bersama guru dengan beberapa metode yang ada seperti demonstrasi, tanya jawab dan lain sebagainya. Ahmad (2016) juga menyatakan bahwa model pembelajaran langsung ini menekankan pada wujud aktivitas siswa dalam mengekspresikan pikiran, perasaan dan imajinasinya dengan menggunakan bahasa tulis.

Model pembelajaran langsung ini memilki sintaks/langkah pembelajaran sebagai berikut: 1) menyampaikan tujuan pembelajaran, (2) guru/model mendemonstrasikan pengetahuan, (3) guru membimbing pelatihan, (4) mengecek pemahaman peserta didik dan memberikan umpan balik, (5) memberikan kesempatan peserta didik untuk pelatihan selanjutnya dan penerapannya (Ni'mah, 2006). Melalui penerapan model pembelajaran langsung, guru memiliki kesempatan untuk mendemonstrasikan keterampilannya. Begitu 
pula peserta didik akan memiliki pegangan untuk melatih diri menirukan mengingat dan menirukan keterampilan yang sudah didemonstrasikan oleh guru sebelumnya. Selanjutnya guru memiliki kesempatan untuk mengecek dan memperbaiki kesalahan dan kekurangan peserta didik.

Beberapa penelitian yang sudah dilakukan antara lain Eka Fitriana Hamsyah, St. Hayatun Nur Abu (2017) yang menemukan bahwa ada pengaruh positif penggunaan model pengajaran langsung dengan pendekatan metacognitive terhadap hasil belajar siswa kelas $\mathrm{X}$ SMA Negeri 1 Sungguminasa pada materi pokok ikatan kimia. Multasyam et al. (2016) menemukan bahwa pretest siswa memperoleh skor rata-rata 7,92 sedangkan posttest diperoleh skor rata-rata 12,74 dan skor rata-rata uji gain ter normalisasi sebesar 0,40 . Sehingga dapat disimpulkan bahwa hasil belajar siswa kelas X SMA Handayani Sungguminasa meningkat dalam kategori sedang setelah diterapkan model pembelajaran langsung. Suprapto (2017) menemukan data penelitian dianalisis secara deskriptif dan ANOVA (Analysis of Variance) yang didasarkan pada taraf signifikansi 5\%. Dari hasil penelitian disimpulkan: (1) penggunaan model pembelajaran contextual lebih unggul dibandingkan dengan model pembelajaran langsung terhadap hasil belajar kognitif, (2) ada perbedaan hasil belajar kognitif yang signifikan antara siswa dengan motivasi berprestasi tinggi dan siswa dengan motivasi berprestasi rendah, dan (3) tidak ada interaksi yang signifikan antara model pembelajaran dan motivasi berprestasi pada hasil belajar kognitif. Dan Puryadi et al. (2018) menyatakan bahwa terdapat pengaruh yang signifikan penerapan model pembelajaran langsung terhadap hasil belajar siswa.

\section{Conclusion}

Setelah dilakukan penggantian metode pembelajaran dari model pembelajaran yang konvensional menjadi model pembelajaran yang constructivism yaitu Model Pembelajaran Langsung ternyata hasil yang diperoleh meningkat pada aspek sikap pada siklus 1 semua anak sudah mencapai kategori baik sedangkan pada siklus 2, kategori amat baik diraih oleh 3 siswa dan kategori baik dicapai oleh 27 siswa. Jadi aspek sikap sudah mencapai tuntas pada siklus 1 . Aspek pengetahuan, pada siklus 1 mencapai ketuntasan $70 \%$ dengan nilai rata-rata 75,6, sedangkan pada siklus 2 baru mencapai ketuntasan $100 \%$ dengan nilai rata-rata 81,17. Dan aspek keterampilan, pada siklus 1 mencapai ketuntasan 73,33\% dengan nilai rata-rata 77,01. Sedangkan pada siklus 2 telah mencapai ketuntasan 100\% dengan nilai rata-rata 81,68. Hasil penelitian ini menunjukkan bahwa penerapan Model Pembelajaran Langsung dalam pembelajaran PJOK dapat meningkatkan hasil belajar siswa.

\section{References}

Ahmad, S. (2016). Pengaruh Model Pembelajaran Langsung Terhadap Kemampuan Menulis Puisi Siswa Kelas X Sma Bina Bersaudara Medan. Jurnal Pendidikan Bahasa Dan Sastra Indonesia, 5(2), 44-59.

Arianti, B. I., Sahidu, H., Harjono, A., \& Gunawan, G. (2017). Pengaruh Model Direct Instruction Berbantuan Simulasi Virtual Terhadap Penguasaan Konsep Siswa. Jurnal Pendidikan Fisika Dan Teknologi, 2(4), 159. https://doi.org/10.29303/jpft.v2i4.307.

Eka Fitriana Hamsyah, St. Hayatun Nur Abu, G. (2017). Pengaruh Model Pengajaran Langsung dengan Pendekatan Metakognitif Terhadap Hasil Belajar Siswa Kelas X SMA Negeri 1 Sungguminasa Pada Materi Pokok Ikatan Kimia Influence of Direct Teaching Approach Against Metacognitive Learning Outcomes Student Class X S. Jurnal Chemica, 18(1), 10-15.

L, H., \& Arsyad, M. N. (2015). Keefektifan Penerapan Model Pembelajaran Langsung pada 
Materi Sistem Gerak di SMA Negeri 1 Donri-Donri. Jurnal Bionature, 16(1), 58-64.

Multasyam, Yani, A., \& Ma'ruf. (2016). Pengaruh Model Pembelajaran Langsung Terhadap Hasil Belajar Fisika Pada Siswa Kelas X SMA Handayani Sungguminasa Kabupaten Gowa. Jurnal Pendidikan Fisika, 4(3), 298-308. http://journal.unismuh.ac.id/index.php/jpf/article/view/328.

Neni Mersita, M. J. (2015). Penerapan Model Pembelajaran Langsung (Direct Instruction) Untuk Meningkatkan Aktivitas Dan Hasil Belajar Pada Mata Pelajaran Kearsipan Siswa Kelas Xi Ap Smk Ype Nusantara Slawi. Economic Education Analysis Journal, 4(3), 634-648. https://doi.org/http://dx.doi.org/10.33578/pjr.v3i6.7898.

Ni'mah, R. F. (2006). Model Pembelajaran Langsung Untuk Meningkatkan Keterampilan Pengambilan Keputusan Siswa Sekolah Dasar Rizka Faidatun Ni ' mah. Jurnal JPGSD, 2(1), 1-13.

Puryadi, P., Rahayu, S., \& Sutrio, S. (2018). Pengaruh Model Pembelajaran Direct Instruction Berbantuan Bahan Ajar Berbasis Kontekstual Terhadap Hasil Belajar IPA Terapan Siswa Kelas X SMKN 4 Mataram Tahun Ajaran 2015/2016. Jurnal Pendidikan Fisika Dan Teknologi, 4(1), 23. https://doi.org/10.29303/jpft.v4i1.329.

Rainis. (2019). Penerapan Model Pembelajaran Langsung Untuk Meningkatkan Hasil Belajar Ipa Rainis. Jurnal PAJAR (Pendidikan Dan Pengajaran), 3(6), 1247-1254. https://doi.org/http://dx.doi.org/10.33578/pjr.v3i6.7898.

Suprapto, E. (2017). Pengaruh Model Pembelajaran Kontekstual, Pembelajaran Langsung Dan Motivasi Berprestasi Terhadap Hasil Belajar Kognitif. Innovation of Vocational Technology Education, 11(1), 23-40. https://doi.org/10.17509/invotec.v11i1.4836.

Yanti, W. (2019). Penggunaan Model Pembelajaran Langsung (Direct Instruction) Untuk Meningkatkan Hasil Belajar Biologi Siswa Kelas X Ipa 1 Sma Negeri 15 Kota Takengon Tahun Pelajaran 2018-2019. BIOTIK: Jurnal Ilmiah Biologi Teknologi Dan Kependidikan, 7(2), 115. https://doi.org/10.22373/biotik.v7i2.5652. 